\title{
Plant expression of cocaine hydrolase-Fc fusion protein for treatment of cocaine abuse
}

\author{
Guojun Wang ${ }^{1,2,4}$, Ting Zhang ${ }^{1,2}$, Haifeng Huang ${ }^{1,2}$, Shurong Hou ${ }^{2}$, Xiabin Chen ${ }^{1,2}$, Fang Zheng ${ }^{1,2^{*}}$
} and Chang-Guo Zhan ${ }^{1,2,3^{*}}$

\begin{abstract}
Background: A recently reported cocaine hydrolase $(\mathrm{CocH} 3)$ fused with fragment crystallizable $(\mathrm{Fc})$ region of human immunoglobulin $\mathrm{G} 1$, denoted as $\mathrm{CocH3}-\mathrm{Fc}$, is known as a promising therapeutic candidate for the treatment of cocaine overdose and addiction. A challenge for practical therapeutic use of this enzyme exists in the large-scale protein production and, therefore, it is interesting to identify a low-cost and feasible, sustainable source of $\mathrm{CocH} 3-\mathrm{Fc}$ production.

Results: $\mathrm{CocH} 3-\mathrm{Fc}$ was transiently expressed in plant Nicotiana benthamiana leaves. The plant-expressed protein, denoted as $\mathrm{pCocH} 3-\mathrm{Fc}$, was as active as that expressed in mammalian cells both in vitro and in vivo. However, compared to the mammalian-cell expressed CocH3-Fc protein, pCocH3-Fc had a shorter biological half-life, probably due to the lack of protein sialylation in plant. Nevertheless, the in vivo half-life was significantly extended upon the PEGylation of pCocH3-Fc. The Fc fusion did not prolong the biological half-life of the plant-expressed enzyme pCocH3-Fc, but increased the yield of the enzyme expression in the plant under the same experimental conditions.

Conclusions: It is feasible to express pCocH3-Fc in plants. Further studies on the pCocH3-Fc production in plants should focus on the development of vectors with additional genes/promoters for the complete protein sialylation and for a better yield.
\end{abstract}

Keywords: Therapeutic protein, Fusion protein, Protein production, Drug abuse

\section{Background}

Cocaine is the most reinforcing drug in stimulating the reward pathway of the brain and teaching the user to take it again [6, 13, 15]. Despite decades of effort, classical pharmacological approaches to antagonizing neuropharmacological actions of cocaine has not proven successful, because it would be extremely difficult to antagonize its physiological effects without affecting normal functions of central nervous system (CNS) [29]. The inherent difficulties of antagonizing cocaine in the CNS led to the development of protein-based therapeutic agents that can tightly bind with cocaine and,

\footnotetext{
* Correspondence: fzhen2@uky.edu; fzhen2@email.uky.edu; zhan@uky.edu ${ }^{1}$ Molecular Modeling and Biopharmaceutical Center, College of Pharmacy, University of Kentucky, 789 South Limestone Street, Lexington, KY 40536, USA

Full list of author information is available at the end of the article
}

thus, prevent cocaine from reaching the CNS or accelerate cocaine metabolism $[21,29]$. In particular, the pharmacokinetic approach with an efficient cocainemetabolizing enzyme is recognized as the most promising treatment strategy for cocaine overdose and addiction [2, 5, 20, 29]. Unlike the stoichiometric binding of an antibody with drug, one enzyme molecule can degrade multiple drug molecules, and the efficacy of an enzyme is dependent on its catalytic rate constant $\left(k_{\text {cat }}\right)$ and Michaelis-Menten constant $\left(K_{\mathrm{M}}\right)$ against the drug.

The principal metabolic enzyme of cocaine in human body is butyrylcholinesterase (BChE) in the plasma, producing biologically inactive metabolites. However, the catalytic efficiency $\left(k_{\text {cat }} / K_{\mathrm{M}}\right)$ of wild-type human $\mathrm{BChE}$ against naturally occurring (-)-cocaine is too 
low $\left(k_{\mathrm{cat}}=4.1 \mathrm{~min}^{-1}\right.$ and $\left.K_{\mathrm{M}}=4.5 \mu \mathrm{M}\right)$ [22] to be effective for $(-)$-cocaine metabolism. Below we will always refer cocaine to $(-)$-cocaine, unless explicitly stated otherwise, for convenience. In previous studies, we successfully designed and discovered human $\mathrm{BChE}$ mutants with at least 1000-fold improved catalytic efficiency against cocaine compared to wild-type human $\mathrm{BChE}$, and these $\mathrm{BChE}$ mutants are recognized as true cocaine hydrolases (CocHs) in literature [2, 17, 25, 27, 28]. The first one of our designed CocHs, known as CocH1 (A199S/S287G/ A328W/Y332G mutant of human BChE) $[17,26]$, was fused with human serum albumin (HSA) to improve the in vivo stability [2], and the obtained HSA-fused $\mathrm{CocH} 1$ is also known as Albu-CocH, Albu-CocH1, AlbuBChE, or TV-1380 in literature $[2,5,20,23]$. Clinical trials demonstrated that TV-1380 is safe and effective for use in animals and humans $([5,20])$. TV- 1380 has a biological half-life of $\sim 8 \mathrm{~h}$ in rats [2] and 43-77 $\mathrm{h}$ in humans [5]. However, its actual therapeutic value for cocaine addiction treatment is still limited by the relatively lower catalytic activity of TV-1380 against cocaine compared to the more recently reported human $\mathrm{BChE}$ mutants, and the costs for large-scale protein production. The lower the catalytic activity of the enzyme against cocaine, the higher the required dose of the enzyme, and thus the higher the costs would be.

Notably, our more recently reported A199S/F227A/ S287G/A328W/Y332G mutant of human BChE, known as $\mathrm{CocH} 3$ [24, 28], is significantly more active against cocaine compared to CocH1. Further, we have recently designed, prepared, and tested a long-acting form of $\mathrm{CocH} 3$, denoted as $\mathrm{CocH} 3-\mathrm{Fc}$ [4], a fusion protein in which the C-terminus of $\mathrm{CocH} 3$ is fused with the $\mathrm{N}$ terminus of fragment crystallizable $(\mathrm{Fc})$ region of human immunoglobulin G1 (IgG1). The CocH3-Fc protein expressed in Chinese hamster ovary $(\mathrm{CHO})$ cells may be regarded as a catalytic antibody analog, because it is as active as the unfused $\mathrm{CocH} 3$ against cocaine with a considerably longer biological half-life (e.g. $t_{1 / 2}=\sim 107 \mathrm{~h}$ in rats) like an antibody [4]. A single dose of CocH3-Fc was able to block cocaine-induced hyperactivity and toxicity for a long period [4].

On the other hand, it has been very challenging to express $\mathrm{BChE}$ and its mutants in a commercially feasible expression platform. For example, the low yield of protein expression in $\mathrm{CHO}$ cells equates with high costs for protein production and ultimately treatment. It is highly desired to identify a low-cost and feasible, sustainable source of $\mathrm{CocH} 3-\mathrm{Fc}$ production for practical application of CocH3-Fc-based enzyme therapy. Generally speaking, rapid, transient expression of a foreign protein in plant is readily scalable for large-scale production with low costs $[7,8]$. Interestingly, Mor et al. have demonstrated that plant can serve as an expression host for wild-type $\mathrm{BChE}[7,8]$ and its mutants $[9,14]$. It has also been known that the plant-expressed $\mathrm{BChE}$ (pBChE) or a $\mathrm{pBChE}$ mutant has a relatively shorter half-life compared to the same protein expressed in $\mathrm{CHO}$ cells due to the lack of complete polysialylation during the post-translational modification (glycosylation) in plant. Nevertheless, co-expression of pBChE with additional genes required for in planta protein sialylation can produce the desired $\mathrm{pBChE}$ with the overall glycosylation profile resembling the plasma-derived orthologue in order to have a much longer biological half-life [19].

The above background shows that plant protein expression is a truly valuable source of protein production for human BChE and its mutants (including $\mathrm{CocH} 3$ ) for practical use. However, it is unknown whether our most recently designed catalytic antibody analog CocH3Fc [4], an Fc-fusion protein, can also be expressed in a plant. We are particularly interested in the Fc-fusion protein, because $\mathrm{Fc}$ portion of the fusion protein lends itself to easier purification using conventional protein $\mathrm{A}$ chromatography, potentially reducing the number of processing steps in the manufacture of $\mathrm{CocH} 3-\mathrm{Fc}$ at large scale. We also wanted to know whether pCocH3-Fc expressed in a plant has a significantly longer biological half-life than the unfused protein $\mathrm{pCocH} 3$ expressed in the same plant. Here we report the establishment of a Nicotiana benthamiana plant expression system for the production of pCocH3-Fc. In comparison with the unfused pCocH3, pCocH3-Fc can be expressed more efficiently under the same experimental conditions. This is the first report of a heterologous expression of an Fc-fused cocaine hydrolase or BChE or BChE mutant in plants.

\section{Methods}

\section{Constructions for plant expression}

Starting from the sequences of human $\mathrm{BChE}$ (accession number P06276 in the Swiss Protein Database), the $\mathrm{CocH} 3$ or $\mathrm{CocH} 3-\mathrm{Fc}$ cDNA was first subjected to codon optimization according to codon bias of $N$. benthamiana, and then cloned via Gateway (Invitrogen) cloning technology into the vector pSITE0A, a member of pSITE family Agrobacterium binary vectors developed by Dr. Goodin for the purpose of protein expression in plant [3]. As illustrated in Fig. 1, various constructions with or without a signal peptide, with or without fusion with Fc fragment were prepared via different combinations of corresponding primers: the coding sequences of amino acids $1-529$ of the CocH3 were amplified with pfu DNA polymerase (Stratagene, La Jolla, CA) by using corresponding templates harboring point mutations A199S/F227A/S287G/A328W/Y332G on human BChE (stocked in this lab) with a forward primer 12-7_F_ENTR (for constructs without $\mathrm{N}$-terminal signal peptide) or 12-7_F_sig_ENTR (for constructions with N-terminal 


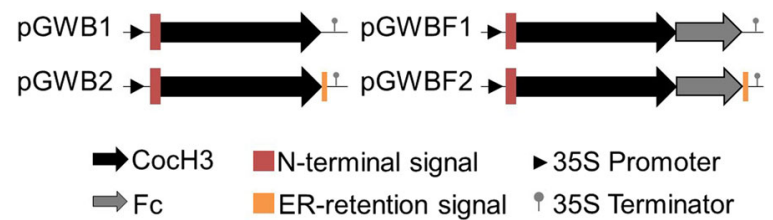

Fig. 1 Diagram of constructs used in this study. $\mathrm{CocH} 3$ : 1-529 amino acids of $\mathrm{CocH}$. Fc: Fc region of human IgG1. N-terminal ER-targeted signal: MDSKVTIICIRFLFWFLLLCMLIGKSHT. ER-retention signal: SEKDEL. Promoter: Cauliflower mosaic virus (CaMV) $35 \mathrm{~S}$ promoter from pRTL2-GUS. Terminator: CaMV 355 terminator from $p R T L 2-G U S$

signal peptide) and a reverse primer 12-7_ $R$ (for constructions without $\mathrm{C}$-terminal signal peptide) or 12-7_R_sig (for constructions with $\mathrm{C}$-terminal signal peptide). The $\mathrm{Fc}$ fragment was amplified by using a forward primer FC_F and a reverse primer FC_R_ENTR (for constructions without C-terminal signal peptide) or FC_R_sig _ENTR (for constructions with C-terminal signal peptide). All of the primers used are listed in Table 1. The CocH3-Fc fusion PCR was done based on 12 bp nucleotide sequences overlapping the 3 '-end of $\mathrm{CocH} 3$ gene and 5'-end of Fc fragment, followed by a full-length PCR using a CocH3 forward primer and an Fc reverse primer. The promoter and terminator used are the cauliflower mosaic virus (CaMV) 35S promoter and the CaMV $35 \mathrm{~S}$ terminator, respectively, from pRTL2-GUS [18].

Transient transfection of $\mathrm{N}$. benthamiana with $\mathrm{pCocH} 3$ or pCocH3-Fc expression constructs

$N$. benthamiana wild-type plants used in this study were maintained by Dr. Michael Goodin's lab in the College of Agriculture Greenhouse operations and facility at the University of Kentucky. The College of Agriculture Greenhouse operations and facility is administered by Facilities Management of the university. Young $N$.

Table 1 Primers used in this study

\begin{tabular}{ll}
\hline Primer & Sequence \\
\hline 12-7_F_ENTR & 5'-CACCATGGAAGATGACATCATAATTGCAACA-3' \\
12-7_F_sig_ENTR & 5'-CACCATGGATAGCAAAGTCACAATCATATG-3' \\
12-7_R & 5'-ATAGAGCTCTTAGACTTTTGGAAAAAATGATGTCCAG-3' \\
12-7_R_sig & 5'-ATTTCAGAGTTCATCCTTCTCAGAGAGACCCACACA \\
& ACTTTCTTCT-3' \\
FC_F & 5'-TTCCAAAAGTCGTGGAGCCTAAGTCCTGCGACAA-3' \\
FC_R_ENTR & 5'-ATTTTACCCGGAGACAGGGAGAG-3' \\
FC_R_sig_ENTR & 5'-ATTTCAGAGTTCATCCTTCTCAGATTTACCCGGAGACA \\
& GGGAGAG-3' \\
\hline
\end{tabular}

benthamiana plants with 4-5 true leaves were used for protein expression in this study. Expression plasmids (see Fig. 1) were transformed into Agrobacterium tumefaciens strain GV3850 following the standard freezethaw method [10]. After confirming the presence of plasmid by clone PCR, A. tumefaciens strains were cultured for overnight in $5 \mathrm{~mL}$ of LB media supplemented with spectinomycin $(100 \mu \mathrm{g} / \mathrm{mL})$, rifampicin $(100 \mu \mathrm{g} / \mathrm{mL})$, and streptomycin $(20 \mu \mathrm{g} / \mathrm{mL})$ on a shaker $(200 \mu \mathrm{rpm})$ at $28{ }^{\circ} \mathrm{C}$, which by a ratio of 1:100 was transferred to fresh YEP medium (http://cshprotocols.cshlp.org/) supplemented with the same antibiotics. After $\mathrm{OD}_{600}$ reached $\sim 0.7$, Agrobacterium cells were collected by centrifugation at $4000 \times g$ for $15 \mathrm{~min}$ at $4{ }^{\circ} \mathrm{C}$, washed twice by using MES buffer (10 mM MgCl, $10 \mathrm{mM} \mathrm{MES,} \mathrm{pH} \mathrm{5.6),} \mathrm{and}$ re-suspended in the MES buffer supplemented with $200 \mu \mathrm{M}$ acetosyringone to $\mathrm{OD}_{600}=\sim 0.7$. The cell suspension was kept at room temperature for $2-3 \mathrm{~h}$, and then used to infiltrate plant leaves by vacuum infiltration. After keeping infiltrated plants in dark overnight, plants were cultured under light (14 h per day) at room temperature. Unless stated specifically otherwise, leaves were harvested at 3 days after infiltration, and immediately frozen in liquid nitrogen and kept at $-80{ }^{\circ} \mathrm{C}$ for use in subsequent experiments.

\section{Protein extraction and purification}

For small scale, leaves were grounded in liquid nitrogen to fine powder which was re-suspended in $100 \mathrm{mM}$ phosphate buffer (PB) (pH 7.4) supplemented with protease inhibitor cocktail (ordered from Sigma) with a ratio of $3 \mathrm{~mL}$ buffer per gram leaves. For large scale, leaves were grounded by a blender (Oster) in the presence of cold PB buffer supplemented with the same protease inhibitor cocktail. For better plant cell lysis, the grounded leaf mixture was passed through a French Press (Thermo Scientific). After centrifuging at $23,000 \times g$ for $15 \mathrm{~min}$ at $4{ }^{\circ} \mathrm{C}$, the supernatant, after filtration through Miracloth (EMD Millipore), was obtained as the crude extract. The crude extract (containing $\mathrm{pCocH} 3$ or pCocH3-Fc) prepared from leaves was used for the initial enzyme activity assays (in triplicate).

Purification of the fusion protein pCocH3-Fc from the crude extract was conducted by using Protein A Fast Flow (GE Healthcare) affinity chromatography [24]. About $1 \mathrm{~mL}$ resin was first equilibrated with $20 \mathrm{CV}(20 \mathrm{~mL})$ of PB buffer, loaded with crude extract ( 200 mL per $1 \mathrm{~mL}$ resin), and washed by $10-15 \mathrm{~mL}$ of PB buffer. Protein was eluted by $10 \mathrm{~mL}$ of $50 \mathrm{mM}$ sodium citrate buffer (pH 4.5), and followed by another $10 \mathrm{~mL}$ of $50 \mathrm{mM}$ sodium citrate buffer ( $\mathrm{pH}$ 3.8). Eluted protein solutions were neutralized immediately with $\mathrm{PB}$ buffer and then concentrated by Amicon centrifuge tubes (Millipore). 
Protein pCocH3 was not purified and $\mathrm{CocH} 3$ purified from $\mathrm{CHO}$-expression system was used [24] for comparison in the kinetic analysis.

\section{Protein PEGylation}

Protein conjugation with polyethylene glycol (PEG) polymer chains (PEGylation) was performed according to a manufacture-provided protocol (JenKem Technology) in order to extend the biological half-life of the protein. Briefly, the purified pCocH3-Fc protein $(1 \mu \mathrm{g} / \mu \mathrm{L})$ was quickly mixed with PEG 2000 at a ratio of 1:300 in $50 \mathrm{mM} \mathrm{PB}$ (pH 7.4), and incubated at $4{ }^{\circ} \mathrm{C}$ overnight. To remove the remaining PEG, protein preparations were filtered with Amicon Ultra-15 Centrifugal Filter Units (Millipore) with abundant amount of $100 \mathrm{mM} \mathrm{PB}$, and finally concentrated to $500 \mu \mathrm{L}$.

\section{In vitro enzyme activity assay}

To monitor the protein expression, the catalytic activity of the crude enzyme ( $\mathrm{pCocH} 3$ or $\mathrm{pCocH}-\mathrm{Fc}$ ) extract against cocaine was assayed rapidly by using $\left[{ }^{3} \mathrm{H}\right](-)$ cocaine labeled on its benzene ring as described previously [17]. Reaction mixture $(200 \mu \mathrm{L})$ containing $10 \mu \mathrm{L}$ of enzyme solution, $50 \mu \mathrm{L}$ of $400 \mathrm{nM}$ cocaine containing $100 \mathrm{nCi}\left[{ }^{3} \mathrm{H}\right]$-cocaine in $0.1 \mathrm{mM} \mathrm{PB}$ was incubated at $25{ }^{\circ} \mathrm{C}$ for $3 \mathrm{~min}$, and stopped by adding $200 \mu \mathrm{L}$ of $0.05 \mathrm{M} \mathrm{HCl}$ which neutralizes the labeled benzoic acid while ensuring a positive charge on the residual cocaine. $\left[{ }^{3} \mathrm{H}\right]$-labeled benzoic acid was extracted by $1 \mathrm{~mL}$ of toluene and measured by scintillation counting. The radiometric data were analyzed as described previously [28].

The final kinetic characterization of $\mathrm{pCocH} 3-\mathrm{Fc}$ against cocaine was carried out on the purified pCocH3-Fc with our previously established protocol using the $\left[{ }^{3} \mathrm{H}\right](-)$-cocaine $[11,24]$.

\section{Subjects for in vivo activity tests}

Male CD1 mice (27-30 g) were obtained from Harlan (Indianapolis, IN) and housed in groups of 4-5 mice per cage. According to our previous experience, different strains of mice are expected to show very similar results for the effects of a given cocaine-metabolizing enzyme. CD1 mice generally have very visible tail veins, which makes the tail vein injection easier. For this reason, the same type of mice were used in our previous in vivo studies on the protein expressed in $\mathrm{CHO}$ cells [4]. All mice were allowed ad libitum access to food and water and were maintained on a 12-h light/dark cycle with lights on at 8:00 AM in a room kept at a temperature of $21-22{ }^{\circ} \mathrm{C}$. Each mouse was used only once. Experiments were performed in the same colony room in accordance with the Guide for the Care and Use of Laboratory
Animals as adopted and promulgated by the National Institutes of Health. The experimental protocol was pre-approved by the IACUC (Institutional Animal Care and Use Committee) at the University of Kentucky.

\section{Enzyme administration}

Mouse was placed in a small restraint (TV-150 STD, Braintree Scientific, Inc., Braintree, MA) that left the tail exposed. The tail was wiped with an alcohol pad, then a 1-ml syringe with a 30-gauge needle (Becton, Dickinson and Company, Franklin Lakes, New Jersey) was used for infusion via a tail vein. The intravenous (IV) injection volume of the enzyme was controlled at $0.2 \mathrm{~mL}$ per $30 \mathrm{~g}$ of mouse body weight.

\section{Determination of the biological half-life in mice}

Mice were injected IV (via the tail vein) with the enzyme (pCocH3 or pCocH3-Fc or its PEGylated form, denoted as PEG-pCocH3-Fc) in the dose of $0.075 \mathrm{mg} / \mathrm{kg}$ body weight. First, the saphenous vein was punctured with a needle. Approximately $\sim 50 \mu \mathrm{L}$ of blood sample was collected into a capillary tube at various time points after the enzyme injection. The blood samples were centrifuged at $5000 \times g$ for $15 \mathrm{~min}$. The isolated serum was tested for the enzyme activity as described above. The data for elimination of the enzyme from the circulation were fitted to a double-exponential equation as described previously [4].

\section{Protection experiment in mice}

Mice were given $1 \mathrm{mg} / \mathrm{kg} \mathrm{pCocH} 3-\mathrm{Fc}$ or saline intravenously (IV via tail vein), and then a lethal dose of cocaine $(180 \mathrm{mg} / \mathrm{kg}$ ) intraperitoneally (IP). Each mouse was monitored for its behavior and vitality for at least $1 \mathrm{~h}$ post injection. Mice injected with saline solution and cocaine were used as the negative control. Experiments were done in triplicate ( $n=3$ for each group).

\section{Results and discussion}

Expression of pCocH3-Fc

Expression constructs containing only a signal peptide to target expression through the secretory pathway (Fig. 1; pGWB1 and pGWBF1) did not result in any detectable protein expression following vacuum infiltration for up to 11 days. However, expression of constructs with ER-retention signal (Fig. 1; pGWB2 and pGWBF2) resulted in detectable enzyme activity 4 and 5 days post infiltration, suggesting that the protein expression was dependent upon the ER-retention signal.

Then, we checked the expression level in the plant leaves after the infiltration of agrobacteria by monitoring the cocaine-hydrolyzing activity of the crude extract. Both enzymes (pCocH3-Fc and pCocH3) were expressed rapidly in plant cells, and peaked on Day 3 after 
Agrobacterium infiltration; then, the cocaine-hydrolyzing activity in the plant leaves gradually went down. Depicted in Fig. 2 is a typical pattern of the enzyme expression in $N$. benthamiana leaves associated with fusion construct pCocH3-Fc. These results suggested that transient expression of the enzyme (pCocH3-Fc or pCocH3) in the plant was quite rapid and efficient, and that 3 days after bacteria infiltration should be the best time to harvest leaves. Our results are remarkably different from the earlier observation that the expression of human BChE or its mutant in $N$. benthamiana plant started at an extremely low level $(<1 \mathrm{mg} / \mathrm{kg})$ within the first eight (or more) days, but was able to continue and reached a peak after 14-17 days post Agrobacterium infiltration [14]. The remarkably different protein expression patterns are likely due to the difference between the vectors used. Specifically, the one used in the current study is a traditional non-replication vector which starts to diminish once it has entered plant leaves, whereas the one used in the earlier study [14] is a viral vector (ICON vector containing some viral functional components) able to replicate in plant cells. The viral vector is also able to communicate/travel between cells when a mobile protein is expressed.

It is notable that, under the same experimental conditions, the expression level of $\mathrm{Fc}$-fused protein $\mathrm{pCocH} 3-$ Fc was always higher than that of the corresponding protein $\mathrm{pCocH} 3$ by about two-fold. After the harvest time was determined to be 3 days, we further expressed pCocH3-Fc and pCocH3 in N. benthamiana leaves for multiple times. The replicate transient transfections

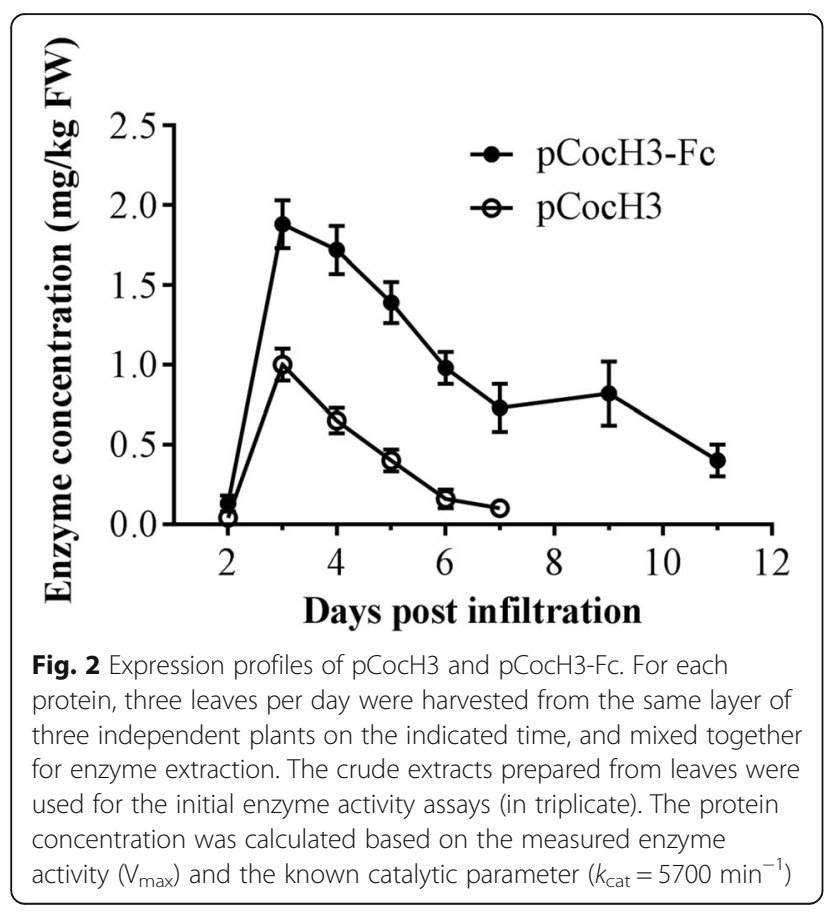

yielded between 2 and $4 \mathrm{mg} / \mathrm{kg} \mathrm{FW}$ for pCocH3-Fc with an average of $\sim 3 \mathrm{mg} / \mathrm{kg} \mathrm{FW}$, while pCocH3 expression ranged between 1 and $2 \mathrm{mg} / \mathrm{kg} \mathrm{FW}$ with an average of $\sim 1.5 \mathrm{mg} / \mathrm{kg}$ FW. So, the Fc fusion approximately doubled the pCocH3 expression in $N$. benthamiana leaves under the same experimental conditions. For comparison, in our previous study [4] of the HSA-fused $\mathrm{CocH} 1$ (Albu-CocH1), the yield of the protein expression in the $\mathrm{CHO}$ cells after the transient transfection was between 1 and $2 \mathrm{mg}$ per liter (L) of culture medium with an average of $\sim 1.5 \mathrm{mg} / \mathrm{L}$. So, the yield of the transient expression of $\mathrm{pCocH} 3$ in the plant is comparable to that of our previous transient expression of Albu-CocH1 in $\mathrm{CHO}$ cells. The average yield of the transient expression of pCocH3-Fc in N. benthamiana leaves is higher than that of the transient expression of Albu-CocH1 in $\mathrm{CHO}$ cells.

It should be pointed out that the average yield of $\sim 3 \mathrm{mg} / \mathrm{kg} \mathrm{FW}$ for pCocH3-Fc is still not high enough for large-scale production at low cost. It is desirable to have a yield of $\sim 100 \mathrm{mg} / \mathrm{kg}$ FW (or more) feasible for large-scale production at low cost. So, it might be necessary to improve the yield by $\sim 30$-fold.

\section{In vitro activity of the purified enzyme}

Fc fusion improved protein expression, but also facilitated protein purification. Very pure plant-expressed CocH3-Fc (pCocH3-Fc) protein (see Fig. 3) was obtained by using the convenient protein A affinity chromatography. However, purification of the unfused enzymes, such as wild-type pBChE, must undergo multiple steps of various chromatography $[8,14]$. In this study, we purified Fc-fused $\mathrm{CocH} 3$, i.e. pCocH3-Fc, by using a one-step affinity chromatography, determined its steadystate kinetics against cocaine and compared it with $\mathrm{CHO}$-expressed $\mathrm{CocH} 3$. According to the data depicted in Fig. 3a, we observed that $K_{\mathrm{M}}=3.0 \mu \mathrm{M}$ and $k_{\text {cat }}=$

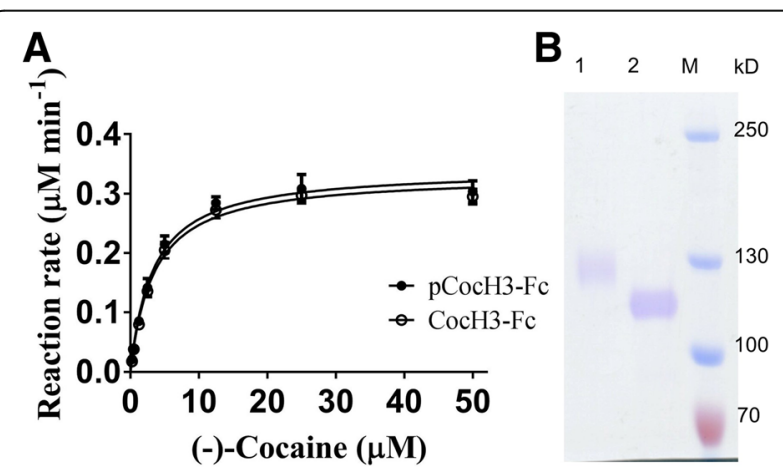

Fig. 3 Kinetic and electrophoresis analyses of pCocH3-Fc and $\mathrm{CHO}$ cells-expressed $\mathrm{CocH} 3-\mathrm{Fc}$. a In vitro kinetic profile of pCocH3-Fc and $\mathrm{CocH3}-\mathrm{Fc}$. The assays were carried out in triplicate. $\mathbf{b}$ SDS-PAGE in which lane $M$ is associated with protein marker, lane 1 with $\mathrm{CocH} 3-\mathrm{Fc}$ expressed in $\mathrm{CHO}$ cells, and lane 2 with $\mathrm{pCocH3}-\mathrm{Fc}$ 
$5770 \mathrm{~min}^{-1}$ for pCocH3-Fc against cocaine; we did not note any significant change in the enzyme activity after the PEGylation (data not shown). In comparison, $\mathrm{CHO}$ cells-derived $\mathrm{CocH} 3$ showed a $K_{\mathrm{M}}$ of $3.1 \mu \mathrm{M}$ and a $k_{\text {cat }}$ of $5700 \mathrm{~min}^{-1}$, suggesting that pCocH3-Fc exhibited a similar catalytic activity against cocaine. These in vitro activity data are also similar to the earlier observation reported by Dr. Mor et al. [8] for the un-fused BChE mutant expressed in plant.

On the other hand, the SDS-PAGE data of the purified proteins also revealed that the pCocH3-Fc protein expressed in $N$. benthamiana leaves had a molecular weight significantly smaller than CocH3-Fc expressed in the $\mathrm{CHO}$ cells, as shown in Fig. 3b. The difference in molecular weight corresponds to the difference in glycosylation between the $\mathrm{CHO}$ and plant expression systems (no determination of glycosylation was made or reported in the paper). As well known, BChE from human plasma is a highly glycosylated protein, and each BChE molecule contains nine sugar chains which accounts for about $24 \%$ of its total molecular weight [16]. The underglycosylated $\mathrm{BChE}$ from an expression system other than mammalian cells was often a major hurdle for establishing a successful expression system of this enzyme, such as goat milk, insect cell and plant cell $[1,8,12]$. The under-glycosylation is expected to affect the pharmacokinetic profile of the protein, although it did not affect the in vitro enzyme activity.

\section{Biological half-life of $\mathrm{pCocH} 3-\mathrm{Fc}$ in mice}

The purified enzymes including $\mathrm{pCocH} 3-\mathrm{Fc}$ and the PEGylated pCocH3-Fc (denoted as PEG-pCocH3-Fc) were tested for their pharmacokinetic profiles in mice. Mice were administered IV with the purified enzyme $(0.075 \mathrm{mg} / \mathrm{kg})$. The blood was sampled at 2,15 , and $30 \mathrm{~min}$, and 1, 2, 4, 8, 12, 24, and $48 \mathrm{~h}$ after the enzyme administration. Depicted in Fig. 4a are the time courses of the active enzyme (pCocH3-Fc or PEG-pCocH3-Fc or $\mathrm{pCocH} 3$ ) concentrations remained after the IV administration of the enzyme materials. The time-course of pCocH3 was determined by IV administration of the crude extract of $\mathrm{pCocH} 3$. For each enzyme sample, the enzyme concentrations ([E]) in the collected plasma samples were analyzed by detecting the enzyme activity $\left(\mathrm{V}_{\max }\right)$ of the plasma, resulting in $[\mathrm{E}]=\mathrm{V}_{\max } / k_{\text {cat }}$. The same $k_{\text {cat }}$ value $\left(5700 \mathrm{~min}^{-1}\right)$ was used for standardizing across samples.

The measured time-dependent concentrations of the active enzymes were fitted to a well-known double exponential equation $\left([E]_{t}=A e^{-k_{1} t}+B e^{-k_{2} t}\right)$ which accounts for both the enzyme distribution process (the fast phase, associated with $k_{1}$ ) and elimination process (the slow phase, associated with $k_{2}$ ). The half-life associated with

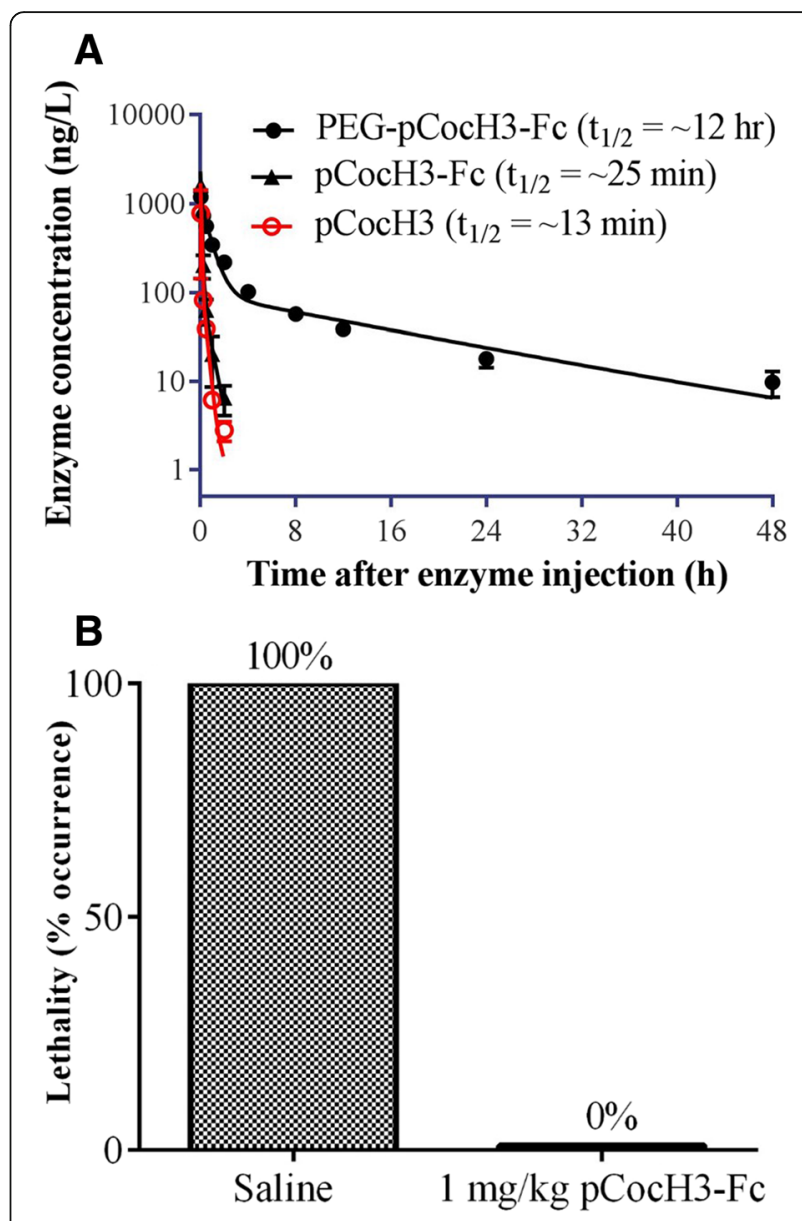

Fig. 4 In vivo profiles of pCocH3-Fc. a Time-dependent concentrations of the active enzyme pCocH3-Fc or PEG-pCocH3-Fc (PEGylated pCocH3-Fc) in the plasma of mice after IV administration of the enzyme $(0.075 \mathrm{mg} / \mathrm{kg})$ determined in triplicate. $\mathbf{b}$ Lethality of $180 \mathrm{mg} / \mathrm{kg}$ cocaine (IP) with or without pretreatment of $1 \mathrm{mg} / \mathrm{kg} \mathrm{pCocH3-Fc}$. The lethality tests were performed in triplicate ( $n=3$ for each group). For the mice survived from the acute cocaine toxicity testing, the observation of animal behaviors was kept for at least $1 \mathrm{~h}$ to make sure that they continued to behave normally after the survival

the enzyme elimination rate constant $k_{2}$ is called the biological half-life $t_{1 / 2}$ (the usually referred in vivo halflife). Thus, we obtained $t_{1 / 2}=\sim 25 \mathrm{~min}$ for $\mathrm{pCocH} 3-\mathrm{Fc}$ and $\sim 12 \mathrm{~h}$ for PEG-pCocH3-Fc, as depicted in Fig. 4. The biological half-life of pCocH3-Fc was only slightly longer than that $(\sim 13 \mathrm{~min})$ of $\mathrm{pCocH} 3$ in mice.

\section{In vivo activity for cocaine detoxification}

We further examined the potential therapeutic value of pCocH3-Fc by using an in vivo protection model [28] used previously for $\mathrm{CocH} 3$ expressed in mammalian cells. Specifically, we wanted to know whether pCocH3Fc can effectively protect mice from the acute toxicity of a lethal dose of cocaine $\left(180 \mathrm{mg} / \mathrm{kg}, \mathrm{LD}_{100}\right)$, because pretreatment with $\sim 1 \mathrm{mg} / \mathrm{kg} \mathrm{CocH} 3$ expressed in 
mammalian cells at $1 \mathrm{~min}$ before the cocaine injection fully protected the mice from such a lethal dose of cocaine $[25,28]$. For the mice survived from the acute cocaine toxicity testing, the observation of animal behaviors was kept for at least $1 \mathrm{~h}$ to make sure that they continued to behave normally after the survival. As shown in Fig. 4b, for the negative control experiments (saline) without administration of the enzyme, IP injection of $180 \mathrm{mg} / \mathrm{kg}$ produced lethality in all mice tested. Pretreatment with $1 \mathrm{mg} / \mathrm{kg}$ pCocH3-Fc at $1 \mathrm{~min}$ before cocaine injection provided full protection in mice after receiving a lethal dose of cocaine $(180 \mathrm{mg} / \mathrm{kg}$, IP). So, the plant-expressed pCocH3-Fc was indeed active in vivo for cocaine detoxification.

\section{Conclusions}

This is the first report on plant expression of the Fc fusion protein form of a cocaine hydrolase or $\mathrm{BChE}$ or BChE mutant, with the goal to know whether the promising $\mathrm{CocH} 3-\mathrm{Fc}$ can be expressed in a plant in any yield. The vector used in the present study might not be advanced enough, but it has been demonstrated that the active pCocH3-Fc enzyme can be expressed in plant $N$. benthamiana leaves with an average yield of $\sim 3 \mathrm{mg} / \mathrm{kg}$ (compared to the average yield of $\sim 1.5 \mathrm{mg} / \mathrm{kg}$ FW for the transient expression of $\mathrm{pCocH} 3$ in $N$. benthamiana leaves and the average yield of $\sim 1.5 \mathrm{mg} / \mathrm{L}$ for the transient expression of Albu-CocH1 in $\mathrm{CHO}$ cells), and that the plant-expressed enzyme (pCocH3-Fc) was as active as the same enzyme ( $\mathrm{CocH} 3-\mathrm{Fc})$ expressed previously in $\mathrm{CHO}$ cells. In addition, the $\mathrm{Fc}$ fusion increased the yield of the enzyme expression in plant under the same experimental conditions, and greatly simplified purification procedure of the enzyme. But it might be necessary to further improve the yield by $\sim 30$-fold before the plant protein expression is feasible for large-scale production at low cost.

Further, it has been known that CocH3-Fc expressed in $\mathrm{CHO}$ cells has a considerably prolonged biological half-life than $\mathrm{CocH} 3$ expressed in $\mathrm{CHO}$ cells [4]. However, when the proteins were expressed in the plant, the biological half-life of pCocH3-Fc in mice was as short as that of $\mathrm{pCocH}$. Combination of the results obtained from the present study and the earlier studies showing a considerably improved biological half-life of the plantexpressed BChE [19] suggests that the in planta protein sialylation is essential for protein $\mathrm{pBChE}$ or $\mathrm{pBChE}$ mutant to have a long biological half-life, whether the protein is fused with Fc or not. In lack of the in planta protein sialylation in the present study, the Fc fusion did not prolong the biological half-life of the enzyme pCocH3 at all. Hence, further development for the Fc fusion protein production in plant should utilize a more advanced vector with additional genes required for the in planta protein sialylation [19]. It is expected that utilization of the more advanced vector would enable to more efficiently produce pCocH3-Fc with the overall glycosylation profile resembling the plasma-derived orthologue. The pCocH3-Fc protein with an improved glycosylation profile is expected to have a much longer biological half-life. Additional genes and proper promoters should also be included in the vector for a higher yield of the enzyme expression.

\begin{abstract}
Abbreviations
BChE: Butyrylcholinesterase; CHO: Chinese hamster ovary; CNS: Central nervous system; $\mathrm{CocH}$ : Cocaine hydrolase; $\mathrm{CoCH}$ : Cocaine hydrolase 1; $\mathrm{CocH3}$ : Cocaine hydrolase 3; CocH3-Fc: Cocaine hydrolase 3 fused with Fc region of human immunoglobulin G1; ER: Endoplasmic reticulum; Fc: fragment crystallizable $(\mathrm{Fc})$ region of human immunoglobulin $\mathrm{G}$; HSA: Human serum albumin; IgG1: Immunoglobulin G1; pBChE: plant-expressed $\mathrm{BChE}$ protein; $\mathrm{pCocH3}$ : plant-expressed $\mathrm{CocH} 3$ protein; pCocH3-Fc: Plant-expressed CocH3-Fc protein; PEG-pCocH3-Fc: PEGylated $\mathrm{pCocH}-\mathrm{Fc}$
\end{abstract}

\section{Acknowledgements}

The authors would like to thank Dr. Michael Goodin for graciously providing pSITE family Agrobacterium binary vectors developed in his lab and N. benthamiana wild-type plants maintained by Dr. Michael Goodin's lab in the College of Agriculture Greenhouse operations and facility at the University of Kentucky.

\section{Funding}

This work was supported by the National Institutes of Health $(\mathrm{NIH})$ through the NIDA Translational Avant-Garde Award (UH2 DA041115) and R01 grants (R01 DA035552, R01 DA032910, R01 DA013930, and R01 DA025100). The funding agency had no role in the design, in the collection, analysis, and interpretation of data, or in the writing of the manuscript; and in the decision to submit the manuscript for publication.

\section{Availability of data and materials}

The datasets during and/or analyzed during the current study available from the corresponding author on reasonable request.

\section{Authors' contributions}

GW designed and prepared the constructions and protocol for protein expression in plant, carried out the protein expression, purification, and in vitro characterization, analyzed the data, and prepared a draft of the manuscript. TZ and HH performed the in vivo studies. SH carried out the in vitro kinetic analysis on the enzymes. XC contributed to the construction preparation. FZ and CGZ designed the project and analyzed the data, with CGZ finalizing the paper. All authors have read and approved the final version of the manuscript.

\section{Competing interests}

The authors declare that they have no competing interests.

\section{Consent for publication}

Not applicable.

\section{Ethics approval}

Human subjects were not involved in this study. This study involved the use of animals. The experimental protocol was pre-approved by the IACUC (Institutional Animal Care and Use Committee) at the University of Kentucky.

\section{Author details}

${ }^{1}$ Molecular Modeling and Biopharmaceutical Center, College of Pharmacy, University of Kentucky, 789 South Limestone Street, Lexington, KY 40536, USA. ${ }^{2}$ Department of Pharmaceutical Sciences, College of Pharmacy, University of Kentucky, 789 South Limestone Street, Lexington, KY 40536, USA. ${ }^{3}$ Chemoinformatics and Drug Design Core, Center for Pharmaceutical Research and Innovation, College of Pharmacy, University of Kentucky, 789 South Limestone Street, Lexington, KY 40536, USA. ${ }^{4}$ Present address: Harbor 
Branch Oceanographic Institute, Florida Atlantic University, 5600 US 1 North, Fort Pierce, FL 34946, USA.

\section{Received: 5 May 2016 Accepted: 13 October 2016}

\section{Published online: 19 October 2016}

\section{References}

1. Brazzolotto X, Wandhammer M, Ronco C, Trovaslet M, Jean L, Lockridge O, Renard PY, Nachon F. Human butyrylcholinesterase produced in insect cells: huprine-based affinity purification and crystal structure. FEBS J. 2012;279(16): 2905-16. doi:10.1111/j.1742-4658.2012.08672.x

2. Brimijoin S, Gao Y, Anker JJ, Gliddon LA, LaFleur D, Shah R, Zhao Q, Singh $M$, Carroll ME. A cocaine hydrolase engineered from human butyrylcholinesterase selectively blocks cocaine toxicity and reinstatement of drug seeking in rats. Neuropsychopharmacology. 2008;33(11):2715-25.

3. Chakrabarty R, Banerjee R, Chung SM, Farman M, Citovsky V, Hogenhout SA, Tzfira T, Goodin M. PSITE vectors for stable integration or transient expression of autofluorescent protein fusions in plants: probing Nicotiana benthamiana-virus interactions. Mol Plant Microbe Interact. 2007;20(7):74050. doi:10.1094/MPMI-20-7-0740.

4. Chen X, Xue L, Hou S, Jin Z, Zhang T, Zheng F, Zhan C-G. Long-acting cocaine hydrolase for addiction therapy. Proc Natl Acad Sci U S A. 2016;113:422-7.

5. Cohen-Barak O, Wildeman J, van de Wetering J, Hettinga J, Schuilenga-Hut P, Gross A, Clark S, Bassan M, Gilgun-Sherki Y, Mendzelevski B, Spiegelstein O. Safety, Pharmacokinetics, and Pharmacodynamics of TV-1380, a Novel Mutated Butyrylcholinesterase Treatment for Cocaine Addiction, After Single and Multiple Intramuscular Injections in Healthy Subjects. J Clin Pharmacol. 2015:55:573-83.

6. Ersche KD, Jones PS, Williams GB, Turton AJ, Robbins TW, Bullmore ET. Abnormal brain structure implicated in stimulant drug addiction. Science. 2012;335:601-4.

7. Geyer BC, Kannan L, Cherni I, Woods RR, Soreq H, Mor TS. Transgenic plants as a source for the bioscavenging enzyme human butyrylcholinesterase. Plant Biotechnol J. 2010;8(8):873-86. doi:10.1111/j.1467-7652.2010.00515.x.

8. Geyer BC, Kannan L, Garnaud PE, Broomfield CA, Cadieux CL, Cherni I, Hodgins SM, Kasten SA, Kelley K, Kilbourne J, Oliver ZP, Otto TC, Puffenberger I, Reeves TE, Robbins 2nd N, Woods RR, Soreq H, Lenz DE, Cerasoli DM, Mor TS. Plant-derived human butyrylcholinesterase, but not an organophosphorous-compound hydrolyzing variant thereof, protects rodents against nerve agents. Proc Natl Acad Sci U S A. 2010;107(47):202516. doi:10.1073/pnas.1009021107.

9. Geyer BC, Woods RR, Mor TS. Increased organophosphate scavenging in a butyrylcholinesterase mutant. Chem Biol Interact. 2008;175(1-3):376-9.

10. Hofgen R, Willmitzer L. Storage of competent cells for Agrobacterium transformation. Nucleic Acids Res. 1988:16(20):9877.

11. Hou S, Xue L, Yang W, Fang L, Zheng F, Zhan C-G. Substrate selectivity of high-activity mutants of human butyrylcholinesterase. Org Biomol Chem. 2013;11:7477-85.

12. Huang YJ, Huang $Y$, Baldassarre $H$, Wang B, Lazaris A, Leduc M, Bilodeau AS, Bellemare A, Cote $M$, Herskovits $P$, Touati $M$, Turcotte C, Valeanu L, Lemee N, Wilgus H, Begin I, Bhatia B, Rao K, Neveu N, Brochu E, Pierson J, Hockley DK, Cerasoli DM, Lenz DE, Karatzas CN, Langermann S. Recombinant human butyrylcholinesterase from milk of transgenic animals to protect against organophosphate poisoning. Proc Natl Acad Sci U S A. 2007;104(34):136038. doi:10.1073/pnas.0702756104.

13. Landry DW, Zhao K, Yang GX, Glickman M, Georgiadis TM. Antibodycatalyzed degradation of cocaine. Science. 1993;259(5103):1899-901. doi:10.1126/science.8456315.

14. Larrimore KE, Barcus M, Kannan L, Gao Y, Zhan C-G, Brimijoin S, Mor T. Plants as a source of butyrylcholinesterase variants designed for enhanced cocaine hydrolase activity. Chem Biol Interact. 2013;203:217-20.

15. Milton AL, Everitt BJ. Wiping drug memories. Science. 2012;336:167-8.

16. Nicolet $Y$, Lockridge $O$, Masson P, Fontecilla-Camps JC, Nachon F. Crystal structure of human butyrylcholinesterase and of its complexes with substrate and products. J Biol Chem. 2003:278:41141-7.

17. Pan Y, Gao D, Yang W, Cho H, Yang G, Tai H-H, Zhan C-G. Computational redesign of human butyrylcholinesterase for anticocaine medication. Proc Natl Acad Sci U S A. 2005;102(46):16656-61. doi:10.1073/pnas.0507332102.

18. Restrepo MA, Freed DD, Carrington JC. Nuclear transport of plant potyviral proteins. Plant Cell. 1990;2:987-98.
19. Schneider JD, Castilho A, Neumann L, Altmann F, Loos A, Kannan L, Mor TS, Steinkellner $\mathrm{H}$. Expression of human butyrylcholinesterase with an engineered glycosylation profile resembling the plasma-derived orthologue. Biotechnol J. 2014;9:501-10.

20. Shram MJ, Cohen-Barak O, Chakraborty B, Bassan M, Schoedel KA, Hallak H, Eyal E, Weiss S, Gilgun Y, Sellers EM, Faulknor J, Spiegelstein O. Assessment of pharmacokinetic and pharmacodynamic interactions between albumin-fused mutated butyrylcholinesterase and intravenously administered cocaine in recreational cocaine users. J Clin Psychopharmacol. 2015;35:396-405.

21. Skolnick P, White $D, A c r i J B$. Editorial: emerging targets for stimulant use disorders: where to invest in an era of constrained resources? CNS Neurol Disord Drug Targets. 2015;14:691.

22. Sun H, Pang Y-P, Lockridge O, Brimijoin S. Re-engineering butyrylcholinesterase as a cocaine hydrolase. Mol Pharmacol. 2002;62(2):220-4.

23. Willyard C. Quest for the quitting pill. Nature. 2015;522:S53.

24. Xue L, Hou S, Tong M, Fang L, Chen X, Jin Z, Tai H-H, Zheng F, Zhan C-G. Preparation and in vivo characterization of a cocaine hydrolase engineered from human butyrylcholinesterase for metabolizing cocaine. Biochem J. 2013;453:447-54.

25. Xue L, Ko M-C, Tong M, Yang W, Hou S, Fang L, Liu J, Zheng F, Woods JH, Tai H-H, Zhan C-G. Design, preparation, and characterization of high-activity mutants of human butyrylcholinesterase specific for detoxification of cocaine. Mol Pharmacol. 2011;79:290-7.

26. Yang W, Xue L, Fang L, Chen X, Zhan C-G. Characterization of a high-activity mutant of human butyrylcholinesterase against (-)-cocaine. Chem Biol Interact. 2010;187(1-3):148-52.

27. Zheng F, Xue L, Hou S, Liu J, Zhan M, Yang W, Zhan C-G. A highly efficient cocaine-detoxifying enzyme obtained by computational design. Nat Commun. 2014:5:3457. doi: 3410.1388/ncomms4457.

28. Zheng F, Yang WC, Ko MC, Liu JJ, Cho H, Gao DQ, Tong M, Tai HH, Woods JH, Zhan C-G. Most efficient cocaine hydrolase designed by virtual screening of transition states. J Am Chem Soc. 2008;130(36):12148-55. doi:10.1021/ja803646t

29. Zheng F, Zhan C-G. Are pharmacokinetic approaches feasible for treatment of cocaine addiction and overdose? Future Med Chem. 2012:4:125-8.

\section{Submit your next manuscript to BioMed Central and we will help you at every step:}

- We accept pre-submission inquiries

- Our selector tool helps you to find the most relevant journal

- We provide round the clock customer support

- Convenient online submission

- Thorough peer review

- Inclusion in PubMed and all major indexing services

- Maximum visibility for your research

Submit your manuscript at www.biomedcentral.com/submit
) Biomed Central 